\title{
Influence of Discovery Search Tools on Science and Engineering e-books Us- age
}

\section{Mr. Eugene Barsky, University of British Columbia}

Eugene Barsky is a Science and Engineering Librarian at the University of British Columbia (UBC). He is interested in engineering information, data management in the physical sciences and has published extensively in the library literature.

\section{Sarah Jane Dooley, Dalhousie University}

Sarah Jane Dooley is Head of Reference \& Research Services and Promotions \& Liaison Librarian at Dalhousie University’s Sexton Design \& Technology Library in Halifax, Nova Scotia, Canada.

\section{Mrs. Tara Mawhinney, McGill University}

Tara Mawhinney is the liaison librarian for Civil Engineering and Applied Mechanics, Mechanical Engineering, and Atmospheric and Oceanic Sciences at McGill University's Schulich Library of Science and Engineering in Montreal, Quebec. Her research interests include new technologies for collection development in science and engineering librarianship, information literacy and social networking sites for teaching and research. She completed an MLIS from McGill's School of Information Studies in 2005.

\section{Zoey Peterson, University of British Columbia}

Zoey Peterson is an MLIS candidate and a student librarian at several libraries, including the Science \& Engineering Library at the University British Columbia.

\section{Mrs. Michelle Spence, University of Toronto}

Michelle Spence is a Reference \& Instruction Librarian at the University of Toronto's Engineering \& Computer Science Library. She holds a H.B.Sc. (2004) and a M.I.St. (2007), both from the University of Toronto. She has held positions in academic and public libraries, as well as a corporate setting. 


\section{Influence of Discovery Search Tools on Science and Engineering e-books Usage}

\section{Introduction}

E-books are becoming an increasingly important part of academic library collections. According to a 2011 report from the American Library Association, ${ }^{1}$ e-books currently represent $27 \%$ of holdings in academic libraries and the numbers have been steadily increasing for years. ${ }^{2}$

Despite this growing importance, providing catalogue access to e-books has always been a challenge for libraries. Traditional library catalogues are based on print collections and do not easily accommodate newer formats. Zhao and Zhao outline some of the inherent challenges that prevent, or at least complicate, the integration of e-books into a traditional catalogue. ${ }^{3}$

Dinkelman and Stacy-Bates discuss the frustrations that users experience when trying to discover e-books through an OPAC and conclude that academic libraries must provide alternative points of access outside of the traditional catalogue. ${ }^{4}$

One promising development in this dilemma is the arrival of web-scale discovery tools such as Summon, Primo, and WorldCat Local. These discovery layers provide a one-stop way to search all of a library's holdings and subscriptions, regardless of format, platform, or vendor. Such tools have already been shown to increase the use of electronic journal articles, ${ }^{5,6}$ but there has been no literature on the impact on e-book usage.

What implications do these new discovery tools have for access to existing e-book collections in science and engineering? This study investigates whether or not the introduction of a discovery layer correlates with an increased use of science and engineering e-books. In this paper, we examine the use of science and engineering e-book collections in four leading Canadian academic libraries - University of British Columbia, McGill University, Dalhousie University, and University of Toronto - to test the hypothesis that introducing a latest-generation discovery search tool, such as Summon or WorldCat Local, in a large academic library correlates with increased usage of major science and engineering electronic resources. The study will compare usage of the following ebook collections, prior to and after implementation of a discovery tool: Books 24x7, Knovel, Springer Link, Synthesis Digital Library and Wiley Online Library.

There are several reasons to expect that the new generation of web-scale discovery tools might have a positive impact on usage of e-books. First, the new discovery tools circumvent some of the cataloging challenges identified by Zhao and Zhao. Second, the new discovery tools promise a unified, one-stop search of all the library's disparate collections, thereby preventing information silos based on format or platform. Third, the new tools allow discovery of e-books 
based on chapter-level metadata or even full-text data, which could potentially make content in e-books more discoverable than in traditionally catalogued print books.

\section{About the libraries in this study}

The Sexton Design and Technology Library is one of five libraries at Dalhousie University in Halifax, Nova Scotia. It is located on the Sexton Campus, and serves the faculties of Architecture, Engineering and Planning. A small campus with approximately 2,300 students within those faculties, it makes up about $13 \%$ of Dalhousie University's total enrollment of approximately 18,000 students.

The Schulich Library of Science and Engineering is the second largest library of a 12-branch library system at McGill University in Montreal, Quebec. It primarily serves undergraduate and graduate students as well as faculty in the physical sciences and engineering. There are currently 4,289 students enrolled in the faculty of engineering and 5,732 enrolled in the faculty of science.

The Engineering and Computer Science Library is one of 44 libraries at the University of Toronto (U of T), and primarily serves all departments in the Faculty of Applied Science and Engineering as well as the Department of Computer Science in the Faculty of Arts and Science. Of the approximately 73,785 students at $\mathrm{U}$ of T, 6,933 are in the Faculty of Applied Science and Engineering.

The Science and Engineering Library at the University of British Columbia (UBC) serves more than 12,000 students, faculty and staff in the Faculty of Applied Science and Faculty of Science in UBC.

\section{Methodology}

In order to investigate the impact of latest-generation discovery search tools, such as Summon or WorldCat Local, on science and engineering e-book usage in a large academic library, we first needed to identify what common e-book packages we had in our four libraries. The following table presents the e-book collections we held most in common. 
Table 1. E-book collections by library

\begin{tabular}{|l|c|c|c|c|}
\hline & UBC & MCGILL & DALHOUSIE & U OF T \\
\hline SPRINGER LINK $^{7}$ & $*$ & $*$ & $*$ & $*$ \\
\hline WILEY ONLINE LIBRARY $^{8}$ & & $*$ & $*$ & $*$ \\
\hline${\text { BOOKS } 24 X 7^{9}}^{10}$ & $*$ & $*$ & & $*$ \\
\hline KNOVEL $^{10}$ & $*$ & $*$ & $*$ & $*$ \\
\hline SYNTHESIS DIGITAL LIBRARY $^{11}$ & $*$ & & $*$ & $*$ \\
\hline
\end{tabular}

In late October 2012, we approached customer representatives for these collections with the request to provide a set of usage statistics from 2008 to 2012. Appreciatively, we must note that all e-book providers supplied their statistics very promptly, mostly in November 2012, and some, namely Books $24 \times 7$, went the extra mile to further collate the statistics for easier use. We are thankful to the publishers for their work with our team.

The four institutions in this study implemented their discovery search engines at different times and in different ways:

- U of T Libraries implemented Summon in September 2011. It became the default search on the main U of T Libraries' home page. [See: http://onesearch.library.utoronto.ca] Other libraries in the U of T Libraries system, such as Engineering \& Computer Science Library, do not default to the Summon search, but rather to the catalogue search.

- UBC Library implemented Summon in April 2011 as the default search engine for the library. [See: http://library.ubc.ca] During the school year, the library sees approximately 7,500 Summon searches per day.

- McGill Library implemented WorldCat Local as a discovery tool in September 2009, initially as a beta catalogue with a link from the library website. In January 2010, WorldCat Local became the default search option for McGill Library. [See: http://www.mcgill.ca/library] Although initially set to search contents of libraries worldwide, it currently searches McGill Library holdings only, including books, e-books, journal articles, etc.

- The Dalhousie University Libraries system implemented WorldCat Local in September 2009. In order to search WorldCat Local, library users must select "books and more" from the search box drop-down menu on the home page. [See: http://libraries.dal.ca] The default setting is to search worldwide. 
Since our institutions implemented the discovery search engines at different times, we have focused on the data for one year preceding implementation at each institution and one year following. For instance, for UBC Library, where implementation took place on April 1, 2011, the usage statistics would be April 1, 2010-March 31, 2011 and April 1, 2011-March 31, 2012. We have also organized the statistics for each e-book platform to see the general trends in full-text usage.

\section{Results}

The data varies significantly for each institution and each e-book package, with some showing large increases and others large decreases in e-book usage after discovery tool implementation (see Tables 2-5). The largest reported increase was $+138 \%$ for Wiley titles at $\mathrm{U}$ of $\mathrm{T}$ and the largest decrease was $-38 \%$ for Springer titles at McGill University. After implementation of WorldCat Local, McGill University saw most of their e-book usage numbers decrease with -38\% for Springer, $-14 \%$ for Knovel and $-2 \%$ for Books $24 X 7$. UBC also saw decreases after implementing Summon with $-16 \%$ for Knovel, $-15 \%$ for Books $24 X 7$ and $-15 \%$ for Synthesis. In contrast, Dalhousie saw an increase in use of all their e-book packages after implementation of WorldCat Local with $+36 \%$ for Springer, $+20 \%$ for Knovel and $+16 \%$ for Wiley. (The data for their Synthesis e-book package was not available for the timeframe we studied.) U of $\mathrm{T}$ saw the largest variability in use of their different e-book packages with substantial increases of $+138 \%$ for Wiley and $+40 \%$ for Springer and decreases of $-23 \%$ for Knovel and $-3.16 \%$ for Synthesis.

Table 2. Summary of e-book usage for Dalhousie University

\begin{tabular}{|c|c|c|c|c|c|}
\hline & $\begin{array}{l}\text { Before and After } \\
\text { Implementation* }\end{array}$ & $\begin{array}{l}\text { Total full-text } \\
\text { downloads }\end{array}$ & $\begin{array}{c}\text { Difference in } \\
\text { number of } \\
\text { downloads (\%) }\end{array}$ & $\begin{array}{c}\text { Number of } \\
\text { Titles }\end{array}$ & $\begin{array}{c}\text { Difference in } \\
\text { number of titles } \\
(\%)\end{array}$ \\
\hline \multirow{2}{*}{ Knovel } & Before & 2986 & \multirow{2}{*}{$+20.03 \%$} & $\mathrm{n} / \mathrm{a}$ & \multirow{2}{*}{$n / a$} \\
\hline & After & 3584 & & $\mathrm{n} / \mathrm{a}$ & \\
\hline \multirow{2}{*}{ Springer } & Before & 21072 & \multirow{2}{*}{$+36.08 \%$} & 3904 & \multirow{2}{*}{$+0.36 \%$} \\
\hline & After & 28675 & & 3918 & \\
\hline \multirow{2}{*}{ Synthesis } & $\mathrm{n} / \mathrm{a}$ & $n / a$ & \multirow{2}{*}{$\mathrm{n} / \mathrm{a}$} & $\mathrm{n} / \mathrm{a}$ & \multirow{2}{*}{$n / a$} \\
\hline & After & 281 & & 28 & \\
\hline \multirow{2}{*}{ Wiley } & Before & 1594 & \multirow{2}{*}{$+15.62 \%$} & 166 & \multirow{2}{*}{$+7502.41 \%$} \\
\hline & After & 1843 & & 12620 & \\
\hline
\end{tabular}


Table 3. Summary of e-book usage for McGill University

\begin{tabular}{|c|c|c|c|c|c|}
\hline & $\begin{array}{l}\text { Before and After } \\
\text { Implementation* }\end{array}$ & $\begin{array}{l}\text { Total full-text } \\
\text { downloads }\end{array}$ & $\begin{array}{c}\text { Difference in } \\
\text { number of } \\
\text { downloads (\%) }\end{array}$ & $\begin{array}{l}\text { Number of } \\
\text { Titles }\end{array}$ & $\begin{array}{c}\text { Difference in } \\
\text { number of } \\
\text { titles (\%) }\end{array}$ \\
\hline \multirow{2}{*}{$\begin{array}{c}\text { Books } \\
24 \times 7\end{array}$} & Before & 116908 & \multirow{2}{*}{$-2.35 \%$} & 26197 & \multirow{2}{*}{$0.00 \%$} \\
\hline & After & 114159 & & 26197 & \\
\hline \multirow[t]{2}{*}{ Knovel } & Before & 7672 & \multirow{2}{*}{$-13.63 \%$} & $\mathrm{n} / \mathrm{a}$ & \multirow{2}{*}{$\mathrm{n} / \mathrm{a}$} \\
\hline & After & 6626 & & $n / a$ & \\
\hline \multirow[t]{2}{*}{ Springer } & Before & 288737 & \multirow{2}{*}{$-37.82 \%$} & 37031 & \multirow{2}{*}{$+17.54 \%$} \\
\hline & After & 179528 & & 43525 & \\
\hline \multirow[t]{2}{*}{ Wiley } & Before & 45672 & \multirow{2}{*}{$+35.28 \%$} & 8336 & \multirow{2}{*}{$+51.39 \%$} \\
\hline & After & 61783 & & 12620 & \\
\hline
\end{tabular}

Table 4. Summary of e-book usage for UBC

\begin{tabular}{|c|c|c|c|c|c|}
\hline & $\begin{array}{l}\text { Before and After } \\
\text { Implementation* }\end{array}$ & $\begin{array}{l}\text { Total full-text } \\
\text { downloads }\end{array}$ & $\begin{array}{c}\text { Difference in } \\
\text { number of } \\
\text { downloads (\%) }\end{array}$ & $\begin{array}{l}\text { Number of } \\
\text { Titles }\end{array}$ & $\begin{array}{l}\text { Difference in } \\
\text { number of titles } \\
(\%)\end{array}$ \\
\hline \multirow{2}{*}{$\begin{array}{c}\text { Books } \\
24 \times 7\end{array}$} & Before & 69263 & \multirow{2}{*}{$-14.78 \%$} & 10620 & \multirow{2}{*}{$0.00 \%$} \\
\hline & After & 59025 & & 10620 & \\
\hline \multirow[t]{2}{*}{ Knovel } & Before & 13899 & \multirow{2}{*}{$-16.04 \%$} & $\mathrm{n} / \mathrm{a}$ & \multirow{2}{*}{$\mathrm{n} / \mathrm{a}$} \\
\hline & After & 11670 & & $\mathrm{n} / \mathrm{a}$ & \\
\hline \multirow[t]{2}{*}{ Springer } & Before & 101278 & \multirow{2}{*}{$+42.47 \%$} & 49951 & \multirow{2}{*}{$+11.06 \%$} \\
\hline & After & 144287 & & 55478 & \\
\hline \multirow[t]{2}{*}{ Synthesis } & Before & 1546 & \multirow{2}{*}{$-15.14 \%$} & $\mathrm{n} / \mathrm{a}$ & \multirow{2}{*}{$\mathrm{n} / \mathrm{a}$} \\
\hline & After & 1312 & & $\mathrm{n} / \mathrm{a}$ & \\
\hline
\end{tabular}


Table 5. Summary of e-book usage for $U$ of $T$

\begin{tabular}{|c|c|c|c|c|c|}
\hline & $\begin{array}{l}\text { Before and After } \\
\text { Implementation }\end{array}$ & $\begin{array}{l}\text { Total full-text } \\
\text { downloads }\end{array}$ & $\begin{array}{c}\text { Difference in } \\
\text { number of } \\
\text { downloads (\%) }\end{array}$ & $\begin{array}{l}\text { Number of } \\
\text { Titles }\end{array}$ & $\begin{array}{c}\text { Difference in } \\
\text { number of titles } \\
(\%)\end{array}$ \\
\hline \multirow[t]{2}{*}{ Knovel } & Before & 14184 & \multirow{2}{*}{$-23.22 \%$} & $\mathrm{n} / \mathrm{a}$ & \multirow{2}{*}{$\mathrm{n} / \mathrm{a}$} \\
\hline & After & 10890 & & $\mathrm{n} / \mathrm{a}$ & \\
\hline \multirow[t]{2}{*}{ Springer } & Before & 136345 & \multirow{2}{*}{$+40.32 \%$} & 43525 & \multirow{2}{*}{$+14.77 \%$} \\
\hline & After & 191318 & & 49952 & \\
\hline \multirow[t]{2}{*}{ Synthesis } & Before & 1487 & \multirow{2}{*}{$-3.16 \%$} & $n / a$ & \multirow{2}{*}{$\mathrm{n} / \mathrm{a}$} \\
\hline & After & 1440 & & $\mathrm{n} / \mathrm{a}$ & \\
\hline \multirow[t]{2}{*}{ Wiley } & Before & 41152 & \multirow{2}{*}{$+138.20 \%$} & 12620 & \multirow{2}{*}{$0.00 \%$} \\
\hline & After & 98027 & & 12620 & \\
\hline
\end{tabular}

\section{Discussion}

The variation in e-book usage between institutions after discovery tool implementation makes it difficult to substantiate the claim that discovery tools correlate with an increased usage of science and engineering e-books. The decrease in use noted at several institutions could possibly be explained by the fact that discovery tools index individual journal articles. As a result, most searches yield a large number of journal articles, potentially obscuring other types such as books (both in print and electronic form), DVDs, theses, etc. For example, a search for "fuel cells" in WorldCat Local at McGill University yields a total of 63,672 results with 63,315 being journal articles and only 192 being e-books (see Figure 1 below): 


\section{Figure 1. Partial screenshot from search for "fuel cells" in McGill University's WorldCat Catalogue (Dec. 15, 2012)}

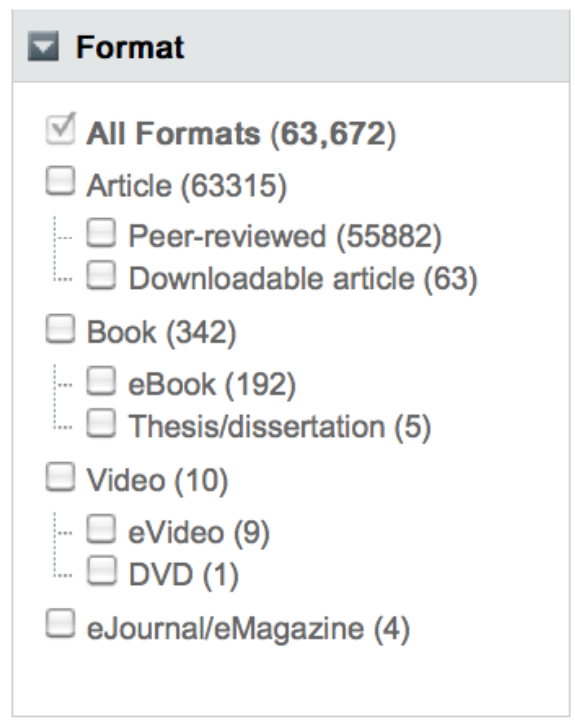

Due to the large number of journal articles in the list of results, users will be more likely to choose articles rather than e-books, which may lead to their decrease usage. Data from UBC illustrates that users of Summon consult mostly the first, second or third hits from the list of search results, as shown in Figure 2 below.

Figure 2. Clicks by position in Summon at UBC

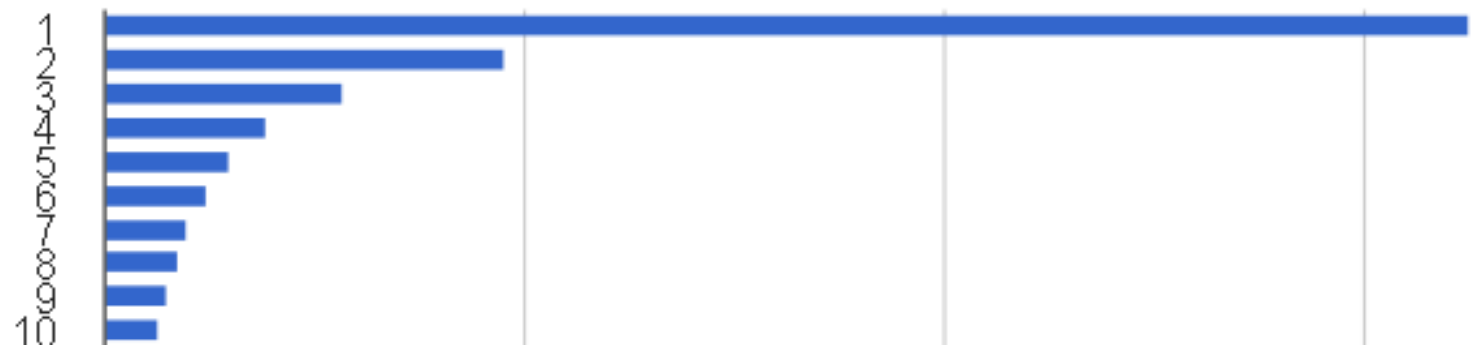

Therefore since most search results in any given search query are likely to be journal articles, it is not surprising that e-books and other types of formats are not as prominent and therefore not used as frequently.

Our study compliments Way's previous study that shows there are increases and decreases in uses of library resources after discovery tool implementation depending on format type. ${ }^{5}$ Way's study shows that there are large discrepancies in use of different formats. While his study does 
not include usage data on e-books with which to compare our findings, he shows that abstracting-and-indexing databases see a considerable decrease in use after discovery tool implementation, whereas full-text collections such as aggregator databases, online journals, and newspapers see a substantial increase in use.

Springer was one e-book package that saw a significant increase in usage in three out of four institutions with increases of $+42 \%$ for $\mathrm{UBC},+40 \%$ for $\mathrm{U}$ of $\mathrm{T}$ and $+36 \%$ for Dalhousie. Springer is indexed at the full-text level in Summon (used by UBC and U of T) and it is the only collection that saw increases within both these institutions. The findings suggest that the use of full-text indexing of e-books within discovery tools results in greater usage. McGill saw a significant decrease in usage of Springer titles of $-38 \%$. However, due to cataloguing difficulties, the majority of Springer e-book titles were not included in the library's classic catalogue or in WorldCat Local during the timeframe we studied, which would likely explain the low usage.

Another e-book package that saw increases in use at three out of four institutions was Wiley with $\mathrm{a}+35 \%$ increase at McGill, $\mathrm{a}+138 \%$ increase at $\mathrm{U}$ of $\mathrm{T}$ and $\mathrm{a}+16 \%$ increase at Dalhousie. However, McGill and Dalhousie had significant increases in the total number of Wiley e-book titles available during the timeframe we studied with a $+51 \%$ increase for McGill and a $+7500 \%$ increase for Dalhousie. In light of the increased number of available titles, it is not surprising that there was an increase in use.

Several factors may contribute to the variability of the findings. First, local implementation decisions at each institution may account for differences in e-book usage. Even institutions that chose the same discovery tool made different decisions about whether or not to include only their own library holdings, those of a consortium of libraries, or those of libraries worldwide. There is even some variation in how the discovery tool was implemented on various library pages at the same institution. For example, the $\mathrm{U}$ of $\mathrm{T}$ uses Summon as the default search engine on the library's central webpage, yet the homepage of the U of T's Engineering \& Computer Science Library uses the classic library catalogue as the default. Furthermore, the ways in which e-book packages are publicized and accessed (e.g. promotion of certain e-book packages by the library, direct links to e-book packages from subject guides, access via Google Scholar, etc.) vary significantly between institutions. Despite the fact that the findings come from four academic institutions with similar user profiles, there are also significant differences in our user groups such as the percentage of graduate students at each institution, differences in full-time enrolment, areas of specialization, etc., all of which may affect use of e-books. Moreover, it is possible that some ebook outliers, such as ebooks used as textbooks for some science and engineering courses could have affected our findings.

Another factor is differences in the discovery tools themselves, with each tool functioning differently from the others. The vendors of each discovery tool have made different decisions 
about the kind of content to include. They have each partnered with different vendors to determine what level of indexing will be included in their master index, and these agreements have changed over time and continue to do so. The functionalities of discovery tools have also changed. For example, there was no discrete facet for e-books when Dalhousie and McGill initially launched WorldCat Local (e-books were grouped under either books or internet resources) and was only added at a later time.

There have also been changes to e-book packages themselves. For instance, the number of available titles has changed over time and also varies between institutions. We have included the number of titles available from each vendor for each institution when such data was available (see Tables 2-5). Also, specific e-book titles have been added and removed from e-book packages, when, for instance, a title changes from one publisher to another. These and other factors may account for some of the variation demonstrated by the data.

\section{Conclusion}

It is apparent from analyzing the usage statistics for multiple universities and e-book packages that usage is influenced by many competing factors, not only the implementation of a discovery layer. The sheer number of articles in a discovery layer overshadows the monographs, whether print or digital. Many Summon users at UBC click on the first couple of results, a characteristic shared by undergraduate students users of Google, who clicked on the first and second result in a study by Granka et al. ${ }^{12}$ In addition, the way in which the discovery layer is presented to the user may impact the usage of materials such as e-books; at $U$ of T, for example, Summon is presented to users primarily as an article search, with the default search set to search journal articles only. As well, some of the more than 44 libraries at U of T have not defaulted to the Summon "search all" option, but have defaulted to the catalogue-only search, which results in materials from the catalogue being searched instead. As a result, it is primarily the catalogue, not Summon, which is the driver to e-book usage at these libraries. The way in which one sets up the discovery layer within an institution can also be a factor in the number of hits an e-book gets. Some are set to only search local holdings, and some are set to search everything in the discovery layer system.

The statistical analysis demonstrates that e-book discovery can be impacted by whether or not vendors allow full-text indexing in discovery layers such as Summon and WorldCat Local. Since many academic libraries are now implementing discovery layers, allowing those discovery layers to search e-books and other resources will increase the discoverability of vendors' and publishers' resources. Not having material searchable in discovery layers was shown to negatively influence the usage of materials. These conclusions are demonstrated by the decrease in usage of Springer e-books at McGill during the time that they were not included in WorldCat Local. Conversely, the usage of Springer e-books increased dramatically at UBC and U of T after the implementation of Summon, since they are full-text searchable in Summon. Collecting and 
analyzing the statistics for this project was illuminating, and after working with the data and analyzing the usage patterns, we have recommendations for vendors. These recommendations include allowing discovery layers to not only index their e-books, but to search the full text in order to increase discoverability and increase the relevance ranking of the e-books in the list of results. In short, better indexing and data availability means increased usage of online resources. In an era where library budgets are tight, being able to prove that a resource is well-used makes an excellent argument for renewing that resource. The value of individual e-books cannot be discounted as well. Vendors such as Knovel or Books 24x7 do not always have control over what the publishers do; in some cases, books have been pulled from these providers by the publishers, and in the case of important handbooks and encyclopedias, this could impact the usage statistics.

Another recommendation for vendors is to collect and provide more detailed data on usage and to collect and provide them in a standardized format. COUNTER compliance would be ideal. Analyzing and comparing the usage data in this study was hampered by the different and often limited data available. This was further complicated by vendors changing platforms, which alters the form in which statistics are reported. Again, when library budgets are tight, having data readily available may mean the difference between a resource being renewed or discontinued. With limited data available, it makes it more difficult to justify the renewal of a resource. With the rise of evidence-based decision making in librarianship, having this data available is critical to librarians' work.

Although the conclusions made in this study are limited, based on the variability in usage among libraries and e-book packages, it's evident that this is an area that could use further study. Changes to how libraries implement discovery layers and how vendors provide librarians with usage statistics will assist libraries - and their patrons - in navigating the often confusing world of academic e-books.

\section{References}

1. American Library Association. Academic libraries. In The State of America's Libraries: A Report from the American Library Association. 2011. Available: http://www.ala.org/news/mediapresscenter/americaslibraries/academic Accessed 12/17/2012.

2. Primary Research Group. Library use of e-books. [New York, N.Y.]: Primary Research Group, 2012.

3. Zhao, S, Zhao W. Addressing the challenge: Cataloguing electronic books in academic libraries. Evidence Based Library and Information Practice. 2010;5.1:93-103. 
4. Dinkelman, A, Stacy-Bates K. Accessing e-books through academic library web sites. College \& Research Libraries. 2007;68.1:45-58.

5. Way, D. The impact of web-scale discovery on the use of a library collection. Serials Review. 2010;36.4:214220. doi: $10.1016 /$ j.serrev.2010.07.002

6. Greiner, Tony. How does switching to a discovery tool affect circulation? Declaration of Interdependence: The Proceedings of the ACRL 2011 Conference. 2011. Association of College and Research Libraries; 2011. Available:

http://www.ala.org/acrl/sites/ala.org.acrl/files/content/conferences/confsandpreconfs/national/2011/papers/how does switching.pdf Accessed 12/17/2012.

7. Springer. "Springer Link.” Available: http://link.springer.com Accessed March 12, 2013.

8. John Wiley \& Sons, Inc. "Wiley Online Library.” Available: http://onlinelibrary.wiley.com/ Accessed March 12, $\underline{2013}$.

9. Books24X7 Inc. “Bookx24X7.” Available: http://library.books24x7.com Accessed March 12, 2013.

10. Knovel Corporation. “Knovel.” Available: http://www.knovel.com/web/portal/main Accessed March 12, 2013.

11. Morgan \& Claypool Publishers LLC. "Morgan \& Claypool Publishers." Available: http://www.morganclaypool.com/page/synthesis.jsp, March 12, 2013.

12. Granka L, Joachims T, Gay G. Eye-tracking analysis of user behavior in WWW search. Proceedings of the 27th Annual International ACM SIGIR Conference on Research and Development in Information Retrieval; 2004;478-479 